\title{
THE PROBLEM OF PHILOSOPHICAL COUNSELING
}

\author{
EL PROBLEMA DE LA ORIENTACIÓN FILOSÓFICA
}

FILIPE M. MENEZES

Universidade de Coimbra

flipmenezes@gmail.com

RECIBIDO: 1 DE JULIO DE 2011

ACEPTADO: 6 DE SEPTIEMBRE DE 2011

\begin{abstract}
I propose a reflection on the core problem of Philosophical Counseling. Philosophical Counseling will only make sense if there is a possibility of converting knowledge into practical wisdom and resorting to it while coping with uneasiness. I argue, however, that Philosophical Counseling is possible not because this relationship is ensured as indisputable evidence, but because it is highly problematic. Hence, to question the possibility of Philosophical Counseling its already in itself a contribution to its assertion as specifically philosophical aiding practice and, therefore, not its refutation.
\end{abstract}

Keywords: Philosophical Counseling, complexity, individual, philosophical practice, practical wisdom, uneasiness, enlightenment, appeasement.

Resumen: Propongo una reflexión sobre el problema central del Asesoramiento Filosófico. Éste sólo tendrá sentido si hay una posibilidad de convertir el conocimiento en sabiduría práctica y recurrir a ella para hacer frente al malestar. Yo sostengo, sin embargo, que no es porque esta relación está garantizada como una evidencia indiscutible, sino porque es muy problemática que se puede concebir la Orientación filosófica cómo práctica de ayuda. Por lo tanto, poner en duda la posibilidad de Orientación filosófica es en sí mismo una contribución a su afirmación y no su refutación.

Palabras clave: Orientación filosófica, complejidad, individuo, práctica filosófica, sabiduría práctica, malestar, clarificación, apaciguamiento.

\section{The relationship between enlightenment and appeasement as proposition and basic background of Philosophical Counseling}

A few months ago, the Research and Development Unit - Language, Interpretation and Philosophy (University of Coimbra, Portugal) gave me the opportunity to initiate an "experimental" work of philosophical consultation. In this context, I received a very anguished patient. I asked her about her expectations concerning philosophical counseling. Her answer was: enlightenment and appeasement. 
This link is crucial for philosophical counseling. It is its main presupposition. Based upon it, it announces, justifies and commits itself. Its entire practice is based on the possibility of reversing the philosophical demand for wisdom into relief. This sums up the expectation of this particular patient and that of many others.

To point out the problematic nature of this relationship's presupposition implies stating that Philosophical Counseling is a problem to itself. However, that doesn't solely mean facing it with difficulty. It also provides it with the basis of sustenance that it requires and places it where it rightfully belongs.

It is exactly because there is a problem concerning the relation between enlightenment and appeasement that Philosophical Counseling makes sense. If the problem didn't exist in the first place, there wouldn't be a reason for one to resort to this kind of counseling. Only experiencing this problem can legitimately justify the building up of a philosophical aiding practice as an alternative or adjunct to the panel of aiding services already available. If there wasn't any difficulty in the creation of a practical wisdom, Philosophical Counseling wouldn't be necessary. It is imperative that arguing around Philosophical Counseling includes this relationship issue between enlightenment and appeasement as a key stone in its matters of reflection and debate. To make this happen is the main goal of this study.

The investment of Philosophical Counseling is that many experiences of distemper come from lack of reflection and so, by acquiring accurate reflection skills, the individual's experience may well be eased.

From this point of view, the experience of uneasiness may be due to a misfit between what is commonly called "personal philosophy of life" (the mental organization of ideas about the world and oneself, beliefs, values and presuppositions that shape our vision of the world and guide our behavior) and the situation in which a person is in. So, one must regard this "personal philosophy of life" as an object of research, making it fitter and more functional.

It's impossible to talk about an adjustment between the "personal philosophy of life" and an experienced situation without mentioning the "objective" features of the situation and, therefore, without an investigation of the "world". Science deals with those investigations and 
thanks to it, our era have reached further than ever in terms of knowledge. The current explicative, predictive and manipulative skills present themselves as a challenge to our imagination. It isn't likely that, at that level, Philosophy has anything truly important to add at this moment.

But all this development hasn't been able to eradicate uneasiness, which seem to find its best spot in our society. However, it is not plausible that uneasiness is solely due to an uneven partition of knowledge among the members of the society. It has never been stated that the problems of ethical and existential guidance have ceased to pose to those who have greater access to knowledge. On the other hand, the social agents with larger influence on collective life are generally surrounded by experts, as is the case of businessmen and politicians. In the end, most of the technical achievements are available to the same people to whom the question of "how to make life worthwhile" hasn't stopped posing itself as a problem.

Thus, the problem of the relationship between enlightenment and appeasement can't be perceived as mere lack of knowledge. The problem is not exclusive to those who, because they aren't properly informed, suffer from uneasiness. It mainly concerns the difficulty in converting knowledge into practical wisdom and in using the bare fruit of technique to make life a "better one". What is presupposed in Philosophical Counseling is not indisputable evidence, but a problem. To deepen the reflection on the problematic relationship between enlightenment and appeasement is probably the most necessary condition in order to obtain some kind of practical wisdom from uneasiness. Away from being an affront to the efforts of Philosophical Counseling, it will be a contribution to reinsure its possibility of being.

Philosophical Counseling presupposes that, by means of a careful interpretation of his or her "personal philosophy of life", an individual may improve the quality of his/her experience. Nonetheless, most authors would refuse an interpretation of this attitude as a resignation before the facts of life. What is intended is actually an active posture - to think of oneself as a way of modifying the state of things responsible for the uneasiness. 
Regarding this point, it is difficult to decide if what is at stake is changing oneself, hence adapting to a particular situation, or actually acting in order to change that situation.

In either case, the aforementioned problem is there. If it comes to acting on one's own beliefs, values and assumptions to make them more consistent and to correct them, then why can't that be done by the science of Psychology? If it comes to changing the world by acting, then why aren't the techno-sciences' solutions enough? Psychology is the science that aims at telling the truth about an individual, so it should be able to provide solutions to problems related to individual experience. And techno-science should be able to offer solutions to change what is changeable in the world.

However, there's a boundary that Psychology isn't able to overcome. The boundary is that of the confrontation between the "healthy" man and uneasiness and the reason with the irrational. There's a frontier that techno-science isn't able to break through. It is at the level of decisions regarding the notion of what should be changed in the world in order to make it better and able to provide us with good experiences.

The contribution of Philosophy should consist of providing different ways of thinking knowledge. For example, questioning the reasons why we find it so difficult to convert knowledge into practical wisdom. The kind of enlightenment demanded by a Philosophical Counseling patient / consultant is, therefore, different from scientific knowledge of oneself and of the world.

On the other hand, that enlightenment, that search for wisdom can't dispense with scientific acquisitions. It is thanks to the insight science gives me of myself and the world around me that I'm amazed of how easy it is to convert that knowledge in meaning for my existence and in a practical guidance tool for my decisions. Philosophical Counseling has to deal with modern difficulties.

The basis for Philosophical Counseling, as its reason and justification for being are given through this problem. The supporting idea of Philosophical Counseling is the difficulty felt by many people in providing meaning and guidance to their lives. It's because the knowledge made available by science doesn't solve this difficulty that it (Philosophical Counseling) may appear as an alternative. 
Through this problem, Philosophical Counseling may also define its means of intervention, its goals and its limits. It should be able to: intervene as a way of enlightening the reasons why knowledge resists a direct application to ethical-existential problems; assume and enabling the goal of turning knowledge into relative wisdom to the sources of uneasiness and the meaning of appeasement; admit that it isn't possible to eradicate malaise from existence and that all possible appeasement is precarious.

Philosophical Counseling is based on the problem of the relationships between enlightenment and appeasement, which first defines it as a process of revelation of what existence holds negative, beyond all the positive saying and as devolution of the unrest to the individual, as I mentioned in another occasion ${ }^{1}$.

\section{Four Feelings found in literature about Philosophical Counseling and its indicative value}

The presupposition that conveys the possibility of converting enlightenment in appeasement is found throughout literature concerning Philosophical Counseling. Also there one can feel what is problematic about it.

One can feel this presence more deeply in the feeling that problems which originate the search for Philosophical Counseling, are directly related to the complexity of the society we live in. It also appears in the feeling that "academic Philosophy" has somehow been misrepresented, deflecting itself from its task: being present on the individual's everyday life, helping him think and act in the righteous direction. It is also clear through the feeling that Psychology isn't able to solve ethical-existential problems. Finally, it pops out in the feeling that "true Philosophy" needs to be rescued, the one Philosophy that provide comfort and guidance to the individual, thus turning to the philosophers of the Hellenic period in the search for inspiration.

\footnotetext{
${ }^{1}$ MENEZES, Filipe M.: A ideia geral do "Aconselhamento Filosófico". Uma introdução ao tema, in Revista Filosófica de Coimbra, n. ${ }^{\circ}$ 39, vol. 20, Universidade de Coimbra, 2011; Pags. 101-140.
} 
I propose some meditation around these feelings. Let's retreat the attempt of stating what Philosophical Counseling is and refer to the way it seeks assertion. Let's suspend the reflection on Philosophical Counseling and concentrate on a self-reflection drill.

Reflection has mainly been focused on the definition of Philosophical Counseling, on the issue of its specificity as opposed to other areas of aiding practice and on the shaping of working models in a consultation's scenario. The moment of self-reflection begins with the question: "With which eyes has Philosophical Counseling been looking at itself?"

In an attempt to indicate, observe and describe itself, Philosophical Counseling has been building up as a practice which aims at bring the ethical - existential questioning and the everyday life closer together. It starts from the problematic notion of the human being as a concerned form of existence in the world, as life that places itself as a problem, towards which one must make choices and establish meaningful connections. This notion of life as a problem has led to the necessity of a hermeneutical attitude through which the individual redefines enlightens - the meaning of his own existence and, in practical terms, uses that refinement to reach a state of appeasement.

By adding to this notion the thought that reflection around philosophical problems is a more or less conscious necessity to all humans and that that necessity cannot be technically suppressed, Philosophical Counseling presents itself as a way of restoring what is genuinely human to Man, the ethical care for himself, for the other, for the world ${ }^{2}$. Therefore, one insist on the idea that Philosophy should return to the world of the common individual to show him that the thoughtful care for his own existence is something innate, which can be developed, improved and, most of all, something that Philosophy consists of an invaluable resource to the construction of a satisfactory life - or, in the worst case scenario, a precious instrument when facing the bitterness of existence and while fighting against uneasiness.

\footnotetext{
${ }^{2}$ For an example of this thesis, see: FERRAZ, Lara Sayão: A necessidade de Exercer o que é Próprio do Homem, in DIAS, Jorge: Encontros Portugueses de Filosofia Aplicada, APAEF, 2008. Pags. 1727.
} 
The four aforementioned feelings possess a high indicative value regarding the problem that goes beyond all this description of Philosophical Counseling.

The feeling that what raises philosophical counseling is a set of problems related to social complexity indicates that the object of Philosophical counseling is communicatively conditioning and, therefore, it is exactly in the communication (in the society) that one should search the sources of uneasiness and the reasons for the difficulty of converting knowledge into practical wisdom.

The feeling that Philosophy turned away from everyday life suggests that the circumstances that surround and define our day-to-day have become so complicated that the answer to the philosophical problems of the meaning of life and existential orientation has to be sought in terms completely different from tradition and from those provided by spontaneous and convivial experience.

The feeling that Psychology has to remain silent about what is fundamental refers to the paradox that the consecration of the human individual as a scientific object has also defined the extent to which it is possible to resort to this knowledge to diminish the existential angst.

The feeling that Philosophy must return to the past in search for inspiration points to a historical-cultural evolution along which the perception of ethical-existential problems has deeply changed and it is now necessary to look for solutions that bear in mind what is modern in our society.

Over the next few sections, we will try to follow each one of these feelings in terms of their indicative value.

\section{The feeling that the problems which arouse Philosophical Counseling concern the complexity of the social environment}

The attempt to justify Philosophical Counseling often leads us to issues of communicative nature, that is, related to society and its modern transformations. This is noticeable, for example, in "diagnosis" which refers to a crisis of values, to an emptiness of meaning, to an excess of economics in people's life and thought, to a surplus search for technical- 
scientific solutions to evil, etc. Thus, in the discussion about Philosophical Counseling lies an invitation to a research about the questions related to the social environment.

Under which conditions can we observe and describe the social environment nowadays? What is our starting point to reach our references regarding this environment?

The notion of "observation" is crucial to our study.

Starting from the notion that all observation is a form (as G. SpencerBrown referred to it), we realize that every act of observation consists of the emergence of a limit, a border with both sides dynamically correlated: one side that corresponds to what is indicated in the observation (the positive side of the form, the "figure") and another side that is in the very act of indicating the indicated (the less highlighted side of the observation, the "bottom") ${ }^{3}$.

The role of the observer is crucial in this operation, because it is he who selects from the "bottom", from the environment, the elements and how to connect them in a certain "figure" or shape. The observed is recognized as a result of a temporary connection between elements belonging to the environment in which they loosely connected before the selection made by the observer. With the indication of the observed, we define the "bottom" itself. Each new observation is an update of a virtual world where possibilities renew themselves over and over.

It is not therefore a marking between two independent ontological fields, once they may only occur in time, the observation is itself a moment of mutual co-individuation of form and means of observation and, thus, an update of a sense that begins to be virtual. The observation reveals itself as a contingent and timed operation of selection, i.e., of distinction between two sides of the same limit: the act of observing and the observed; the bottom and the figure, the environment and the positive side of the form. In this sense, the reference to the environment is part of the genesis and evolution of the environment itself. The environment loses its ontological status forever and becomes a narrative element.

\footnotetext{
3 For the concept of "observation", see: LUHMANN, Niklas: La Ciência de la Sociedad, Universidad Iberoamericana, A.C., Lomas de Santa Fé (México), 1996, especially § 2, "Observar". Pags. 55-91.
} 
The self-reflection of Philosophical Counseling begins with the realization that the reference to social complexity as a motivation for the search of Philosophical Counseling is a product of that same complexity and the possibilities of semantic selection available in communication among society. It is from the several semantic possibilities virtually available in the society's environment that Philosophical Counseling may select its conception of uneasiness which may be fought by means of philosophical activity, although not by techno-science.

But these possibilities don't run themselves out in the assertion of a crisis of values, lack of meaning or even of a surplus of economics. They also allow us to admit, as a source of uneasiness, for example, the oppressive force the moral systems may have or the excess of possibilities in arranging meaning. The communicative environment which we connect to allows us a huge discrepancy of possible configurations of meaning and there is no way this disparity can be solved in a single way.

It is necessary to explain to which communicative structure of society this increase of contingency matches and which responsibilities does it hold regarding the difficulties that may lead one to search help in Philosophical Counseling. More specifically, we should ask ourselves under which communicative conditions did a semantic of enlightenment and appeasement re-updated in contemporaneity, connected to the topic of a philosophical practice integrated in an aiding activity against the experience of uneasiness.

The question that requires our attention is: "which aspects related to the social environment are in the origin of perceiving that the specialized activity in the production of knowledge and technical solutions can't successfully be converted into practical wisdom, which the individual can use in his quest for meaning and fulfillment for his own life?"

This question raises two others: "what kind of activity would enable the formation of practical wisdom?" And: "What would appeasement (that this practice could provide) consist of?"

In short: in the end, bearing in mind the current communicative conditions how does one produce enlightenment in order for it to be in the origin of philosophical practice and to what extent can that practice be translated into relief from uneasiness? 
The feeling that the problems of Philosophical Counseling are environmental doesn't forcibly lead us to the usual "diagnosis". It necessarily leads us to the conclusion that our perception of current problems depend on how society builds its structure and finds in itself a way to process meaning in communication.

With the analysis of the second feeling we shall focus our approach to the problem of Philosophical Counseling in this structural issue.

\section{Feeling that philosophy turned away from everyday life}

Literature around Philosophical Counseling denounces that, in the Philosophy studied and produced at Universities, there is a gap regarding the world, the people and society's daily problems ${ }^{4}$. It sees in conceptual technicality and in the mazy semantics of contemporary Philosophy something like alienation towards the true demands that life poses to the individuals. Implicitly, it derives from the fact that it is difficult for most people to follow a philosophical argument, the reverse assumption that, by becoming mazy, the philosophical speech becomes unable to say anything regarding the common. Therefore, a more authentic Philosophy will be the one that sprouts from the fertile soil of daily experience, the one that can be said in simple language that most people understand and, most of all, the one that can provide a means of practical guidance, building itself as a medium between knowledge and action and searching forms of knowledge the individual may use while adopting and attitude regarding his life.

What is pointed at "academic Philosophy" is mainly its incapacity to make itself worthy in everyday life at the level world experiences lived by the individuals.

Why is it so hard for Philosophy to build itself as an available and useful practice for the individual? Is it about a difficulty, which solely concerns to outsiders, in following the vocabulary and the critical tangle of Tradition? If that's the case, hasn't the same issue already been posed to the "professional philosopher"? Doesn't he himself also lead an

\footnotetext{
${ }^{4}$ See, for exemple: MARINOFF, Lou: Mais Platão, Menos Prozac, Editorial Presença, Lisboa, 2001, pag. 22.
} 
"everyday life"? Is it then easier for him than for all the others to convert his philosophical knowledge into practical wisdom applicable to that dayto-day? But then, what's the explanation for the fact that, at a certain moment, the problems that Philosophy dealt with became so complicated that scientific specialization has become inevitable? Which problems has Philosophy answered to, by giving rise to all those subjects which modern society empowered as Science? If it could solve them without the necessity for such transmutation, then wouldn't it have done it already? And now, has Philosophy been covered by sciences or has it already been replaced by them? Sciences have, therefore, suppressed the problems which originated them? Haven't sciences themselves build up as sources of problems to which, in the evolution of their own expertise, they couldn't find solutions? And, if that's the case, isn't it possible to pinpoint an important aspect for the understanding of the evolution of contemporary Philosophy and, specifically, for the figure of Philosophical Counseling?

We can relate some of the difficulties that the practical contemporary Philosophy faces with the perception of a socio-cultural evolution in along which truth and good, theory and practice, knowledge and wisdom, a perfect synchrony has become unlikely.

One of the most interesting aspects of N. Luhmann's thought is the possibility of detecting, among society, a justification for these problems.

According to the author, the way society differentiates itself from its environment determines the conditions in which all communication is possible. The topics, problems, thesis, arguments, concepts, connections of meaning which can successfully be conveyed depend ultimately on the organization of a society. With the evolution of society, it is the horizon of possibilities itself that changes.

Defining society as a system of all possible communications ${ }^{5}$, social environment ceases to be able to be conceived from anthropological fundaments. Its way of working is no longer explainable from the attributes of the human individual, his intentions or his will. Intentions, values, attitudes, expectations, individual ambitions have somehow become irrelevant for what happens in society. What defines the system

5 LUHMANN, Niklas: Comunicación y sociedad, in LUHMANN, Niklas: Complejidad y modernidad: de la unidad a la diferencia, Editorial Trotta, Madrid, 1998. Pags 25-67. 
is that all its operations are operations of communication and that all its elements are communicating elements. Evidently, society's communication needs human individuals to take place and whatever happens at the level of human individuals somehow reverberates on the communication system, in the same way that whatever happens in communication somehow affects the individuals that participate in it. On the other hand, if the definition of society is a communication system, it is precisely in its environment that psycho-physical, participating individual units take position. These units may, in turn, be conceptualized as systems of conscience and perception towards its social environment, from which they structurally and operationally differ.

In short, what defines society is that it is a communicative system in which environment are the human individuals themselves - those are not elements of it and they cannot determinate what happens in society.

This means that society internally regulates its responses to events that come from an environment build up by individuals, the same way that individuals autonomously regulate their responses to the stimuli of the social environment. While that regulation is communicatively performed by society, in the individual's case, these are mental operations. The operating mode of both is essentially diverse, they obey different rules, they possess different rhythms and evolution, so it's highly unlikely that they obtain, at any given time, perfect synchrony among each other.

However, there is something in common which allows these two distinct systems (individual and society) to couple: the fact that they both work on a basis of processing meaning, so this dyssynchrony between mind and society is in fact a dyssynchrony between meaning that is communicatively processed and meaning processed in the mind. The connections of meaning which occur successfully in communication are independent from those produced at the level of thought. An individual can't think about everything that is communicated and that same individual cannot convey everything he thinks. The complexity of countless systems of conscience shapes the environment, which, at the same time, provides the opportunity and necessity to communicate, that is, society. However, in order to work, society needs to find ways to reduce this complexity by selecting elements which can be communicatively processed and rejecting all others. In the same way, the 
complexity of conveyed meaning is part of the environment of individual conscience, thus a source of possibilities and disturbance. The excess of communicative possibilities poses a threat to the stability of the psychic system because it introduces complexity, which it will have to be able to reduce and process in thinkable meaning, or it may become dysfunctional and eventually disintegrate.

The system of society, although operationally closed (in that it may only resort to its own elements and operations to define itself and extend in time) receives from the psycho-physical environment (a set of individuals) the information that it must be able to process and regulate on its $\mathrm{own}^{6}$. Under this disturbing influence, the inner complexity of the systems tends to increase and, therefore, the system must engender mechanisms to be able to reduce it. One of those mechanisms is its inner differentiation. In simpler societies, in which interaction among participants in the system of society is still possible and can ensure a certain stability, that differentiation begins as a territorial segmentation, leading then to a strict model of stratification, as social complexity increases. With the evolution of this latter form of differentiation, communication tends to polarize, to find a center for its diffusion, which, paradoxically, contributes to an increasing empowerment of specialized subsystems in certain types of communication, like politics or law. Without ever cancelling the previous forms of differentiation, others will in the meantime overlap them. These others are more capable of coping with complexity, while the first ones start to serve more particular needs of communication.

According to N. Luhmann, the modern phase of society's evolution is defined by a form of functional differentiation ${ }^{7}$ in which, not having completely lost its importance, territoriality and sense of belonging to a certain layer of society, the access to communication no longer entirely depends on these settlements. Whatever the communicative position one may take at a certain moment, all individuals necessarily participate in all

\footnotetext{
${ }^{6}$ LUHMANN, Niklas: La Ciência de la Sociedad, Universidad Iberoamericana, A.C., Lomas de Santa Fé (México), 1996. Pags. 13-54.

7 LUHMANN, Niklas, Diferenciación Social y Sociedad Moderna, in LUHMANN, Niklas: Complejidad y modernidad: de la unidad a la diferencia, Editorial Trotta, Madrid, 1998. Pags. 71212.
} 
subsystems: politics, law, economics, science, etc. From the standpoint of society, each of these subsystems may be taken under account in the perspective of the role they play regarding a system of society. Thus, Politics and Law may be considered as specialized communication in the transmission of mandatory decisions; Economics may be regarded as a specialized communication in the circulation of scarce goods; Science as a means communication of distinction between true and false; Love as communication on intimacy, etc. By specializing in different tasks and operations of communication, each subsystem acquires a certain operating autonomy in relationship to all others and each must select from the available information in society, the one that is relevant for itself. By doing so, they have developed their own schemes of perception and internal mechanisms of processing perceived information. As a consequence, each subsystem has become an independent center of reflecting society within society, i.e., each subsystem somehow reflects and perceives society, itself and other subsystems. The system of society can therefore perspective itself, if one regards as reference of observation another subsystem, as an internal environment of that subsystem. However, that internal environment may not be perceived in its unit or its whole singly by any of the subsystems, because, for each one of them, it will be perceived as a different internal environment

The differentiation of a functional subsystem of society requires the establishment of strong operational relationships among a certain number of elements that, by being available in the system of society, could differently connect in another sub systemic formation. This means that a subsystem consists in a double reference: itself (that which defines it as a subsystem, the selected elements and the operations through which they connect) and its environment (that horizon of possibilities which allowed the selection and which the subsystem defines as being odd to it. It also restructures itself simultaneously with each new selective operation). Self reference and hetero reference are, therefore, the two sides of the form of society's subsystems, so we figure that none of the subsystems of society is able to observe the whole and the unit of the system of society, the same way that no subsystem could ever observe another subsystem in its environment, as would a third subsystem. 
This is the reason why $\mathrm{N}$. Luhmann refers to the functionally differentiated society as a society without centre or peak ${ }^{8}$. In it there is no privileged observation point, from which its total unit can be seen, keeping itself, among the different sub systemic centers of society's reflection, a permanent quarrel of points of view, in which each one tries to assert its supremacy over the others. What is actually extraordinary is how, despite it (or thanks to it) there is still a society or, as N. Luhmann puts it, may the improbability of communication still convert itself into its probability 9 .

Without loosing sight of these notions, we realize the difficulty of modern individual in reducing information to an unitarian meaning of experience and achieving an ethical canon that ensure effective guidance through the various moments and dimensions of personal life. He doesn't survive without participating in society but he doesn't find in it the image of his truth anymore. He does find in it the necessary environment for the practice of his freedom, but he doesn't escape its constraints and contradictions. He is summoned to participate in all its communicative subsystems, but he constantly sees his capacity to influence it (in a decisive manner) jeopardized.

Many people's difficulties are due to this complexification of society and the relationships between conscience and communication, so they search relief in Philosophical Counseling.

If there is, by chance, something like a detour of Philosophy towards the everyday life, that problem is not related to "academic" Philosophy, but to the outcome of society's evolution in terms of its relationship with systems of conscience and in terms of internal differentiation. It simply ceased to be possible to determine common sense, a single and communitarian meaning capable of providing total and unitarian meaning and to guide the experience.

As a participant in the different communication subsystems of society, the individual will operate by processing the meaning of his existence resorting to different codes or, as N. Luhmann calls them, means of communication symbolically generalised. These codes add to language in

\footnotetext{
${ }^{8}$ BALSEMÃO PIRES, Edmundo: A Sociedade sem Centro - Diferenciação funcional e unidade política da sociedade. A partir da obra N. Luhmann, Autonomia 27, Azeitão, 2004.

${ }_{9}^{9}$ LUHMANN, Niklas: A improbabilidade da comunicação, Vega, Lisboa, 2006. Pag. 51.
} 
order to allow specific forms of communication and share with it the characteristic through which they structure systems of difference or bivalent distinctions. That is, they organize communication based on distinction (observation) between opposite counterparts of values. By participating in the way of communicating truth, the codification performed by the individual settles between true and false; while participating in a communication of power, meaning is codified by the opposites ruling/being ruled; while participating in a legal system, the distinction is between fair unfair; while participating in economic communication, the selection appears in terms of having/not having, etc.

It is easy to understand that contingency defines the possible relations among the different terms of the several opponents. What is True may either be matched with a position of ruling, or with one of opposition; it may be matched either with fair or unfair; having or not having; beauty or ugliness, and so on.

The ethical point of view, i.e., the one that is based on the distinction between what ought to be chosen and what ought to be despised, isn't able anymore to find its stable support on truth nor on any of the other positive values of each opposition ${ }^{10}$. Whatever the reference it assumes as a starting point, it will always bump into the possibility of its opponent or on the incapability of deciding what is better, preferable to all other options. The existential point of view, i.e., the one that is based on the distinction between what is a reflexive and authentic relationship with existence itself and life in its daily rush has irreversibly lost any chance of overcoming the diversity of experiences in unitarian meaning. M. Foucault sums up the difficulties brought by all this saying that our culture makes such a reading of the world that the human being no longer recognizes himself in $i t^{11}$.

We need a Philosophy capable of thinking from this modern way of grasping the world. It wasn't about a detour towards the daily life, but about the recognition that much of the daily life is unrecognizable.

\footnotetext{
${ }^{10}$ BALSEMÃO PIRES, Edmundo: O pensamento de Niklas Luhmann como teoria crítica da moral, in SANTOS, José Manuel: O pensamento de Niklas Luhmann, Lusosofia press, Covilhã, 2005. Pags. 253-280.

${ }^{11}$ FOUCAULT, Michel: Doença mental e psicologia, Edições Texto \& Grafia Lda, Lisboa, 2008. Pag. 98.
} 


\section{The feeling that Psychology hushes when facing the fundamental}

There has been an attempt to claim the specificity of Philosophical Counseling as opposed to Psychology or Psychiatry.

Despite assuming their true importance and value in the treatment of morbid conditions, one also try to show that the very concept of "illness" is hesitant, depending on a sociological conditioning and also on economic and corporative interests. One also denounce the excessive resort to medicine in the treatment of depressive and melancholic conditions, anxiety and stress. Psychotherapy is seen as having a tendency to naturalist prejudice which withdraws value from the human capacity to let itself get affected by ethical-existential questions to the detriment of explanations and ways of treatment inspired in Biology and of a determinist vision of how psychic structures work. Psychoanalysis is ascribed a humiliation of the human being in the sense that it considers the human thought and behavior an expression of unconscious activity and denial of rational will. However, what is deeply at stake is the progressive imprisonment of the concept of uneasiness in that of illness. The argument is that uneasiness belongs to the condition of being concerned about existence and the feeling that one must take on an ethical position in the world. It cannot be mistaken for morbid degeneration. Thus, Psychiatry and Psychology are responsible for the treatment of illnesses. But, is to Philosophy the responsibility for the treatment of philosophical problems ${ }^{12}$.

In the history of Psychology, one identify a moment when the therapists, because they had philosophical education, were more able than today to understand and relieve uneasiness. But it has been stated that that moment has given way to another one in which, at universities, philosophical education has been depreciated and it was given priority to the teaching of technical features of psychotherapy, thus contributing to the entanglement of illness and uneasiness ${ }^{13}$.

\footnotetext{
${ }^{12}$ MARINOFF, Lou: As Grandes Questões da Vida, Editorial Presença, Lisboa, 2005. Pag. 22.

${ }^{13}$ This is, for exemple, the perspective of Peter Raabe: Éstas [las "psicoterapias"] funcionaron muy bien en la época de los pioneros porque los terapeutas se habían formado en filosofía. Cuando, más tarde, enseñaran sus teorías en universidades y clínicas, los alumnos que las recibían habían sido formados fundamentalmente en los aspectos más científicos de la psicología. De este modo, la base filosófica de los primeros psicoterapeutas se diluyó en un pobre método desviándose de la base
} 
This perspective seems to forget the contribution of psychiatry, penchant for existential-phenomenological, of logotherapy and existential analysis which place, in the centre of their theories and practices, the concern for the understanding of the worldvision of individuals who suffer from illness or psychic malaise and advocate a clear claim of rapprochement between Psychology and Philosophy.

The main gap, however, lies on the unspoken consequences regarding the perception of what Psychology has lead us to believe of what an individual is. Philosophical Counseling, in its paratherapeutic application, consists of a service of individual help. But, thanks to Psychology, we now know that what we call an individual doesn't designate an entity that is impartible, identical to itself and simple in the diversity of its updates. Moreover, we know that everything we perceive as individual entity including the perception of ourselves - is the timed, contingent and evolutional outcome of a set of operations performed at the level of our mind. We can no longer regard the individual as something there, placed in a world independent from an observer, solely waiting for his representation in some already individualized mind. We can only identify an individual by means of an act of donation of meaning, through which one can co-differentiate individual observed thing from the individual as an observer. So, Philosophical Counseling begins when the following questions are raised: how does one think this reality in permanent individualization? How (if) is it possible to go from the problem of non coincidence between the self and the individual to a way of knowing that it can be used as practical guidance?

Modern Psychology began and built itself from the contradictions of human experience and tried to extinguish them through positive knowledge. However, as that knowledge evolved and moved forward, it became clear that the truth of any individual, ill or sane, can't be entirely shed on the positivity of knowledge and also that to every positive knowledge there is an amount of negativity, which always remains

reflexiva de sus orígenes. Desgraciadamente, los nuevos terapeutas graduados pensaron erróneamente que su educación científica podría compensar las lagunas dejadas por la ausencia de herramientas filosóficas. RAABE, Peter: "Introducción: Mentes, Cerebros y Filosofía Aplicada", in: DIAS, Jorge e BARRIENTOS RASTROJO, José: Felicidad o Conocimiento?, Doss Ediciones, Sevilha, 2009. Pag. 15. 
tameless. The individual emerges as a clashing reality in himself, consisting of an undecidable ambiguity. As M Foucault wrote, dans les formes actuelles de psychologie on retrouve ces contradictions sous l'aspect d'une ambiguïté que l'on décrit comme coextensive à l'existence humaine ${ }^{14}$.

Psychology has tried to tell the truth about the human individual. Here it is: a broken structure; an impossibility of completely seeing and declaring to itself; the impotence to derive a correct option of an individual's last truth.

This perception of the individual as a fatally clashing reality is in the origin of the introduction to Philosophical themes in psychotherapeutic practice. The meaning a patient gives his illness, the way he tells himself, the meaning he gives his history, the way he places himself in his community and in the world, the choices he makes, the axiological criteria he resorts to - at long last, all kinds of aspects related to ethical and existential questions, become highly relevant for psychotherapy. Gradually, mental illness ceases to be considered through analogy with physical illness and it becomes recognizable that it has a structure related to the evolutive nature of the individual's psychic structures and to his inevitable exposition to the possibility of degeneration. It also becomes recognizable that it has an historical dimension influenced by tensions between past and present, in which the answers given to traumatic events from the past condition the meaning of current situations but in which, at the same time, these new meanings may re-update and intensify the bitterness caused by past traumas; it becomes recognizable that it has an existential dimension which appeals to an analysis of disorders in the meaning that the patient gives his illness and the world around him and on how his system of beliefs and values interfere at the level of symptoms; it has also been noticed the relationship between illness and sociocultural fitting that defines the way through which society tries to silence its internal contradictions and morally suppress traces in which it refuses to recognize itself ${ }^{15}$. In short, it is understandable that the true knowledge about the individual can only be given as an update of

\footnotetext{
${ }^{14}$ FOUCAULT, Michel: La psychologie de 1850 à 1950 (1957), in FOUCAULT, Michel: Dits et écrits I, 1965-1975, vol. 1, Gallimard, Paris, 2001. Pags. 136 e s.

${ }^{15}$ FOUCAULT, Michel: Doença mental e psicologia, Edições Texto \& Grafia Lda., Lisboa, 2008.
} 
meaning through which it simultaneously reshapes the field of the unspoken as an open horizon of possibilities. That is, that the positivity of scientific speech builds itself like a border between what is said by knowledge and what can't be known at that moment; like a positivenegative form.

With Psychoanalysis, Psychology has tried to solve the problem of the conflict between positive science and the individual's negativity in an astonishing way. What Freud and his supporters did was finding a special way of scientifically and positively restoring negativity to the human individual. The novelty and scandal of it, as M, Foucault pointed, wasn't the assertion of man's negativity, but the fact that they reversed the perspective towards the value of the unconscious, by providing it with positive value and attributing negative value to conscience, irrationality, science, art and all other major acquisitions of civilization ${ }^{16}$. All psychoanalytical hermeneutics matches the effort of decoding the unconscious, always updating in a very single manner, the individual's positively readable behavior, which leads to the particular consideration that what is positively observable is what really is negative and that the negative instance, which never fully reveals itself to the eye or thought, is the positive core of all human activity. The manifested significations in the patient's mental universe and in his behavior match the symbolic expressions of the unconscious's language and one needs to analyse them in order to access its latent and deep meaning. The morbid symptom is, hence, an access door to a personal history of life, along which the experience of ambivalence acquired the meaning that, unconsciously, it found certain solutions which ended up being reabsorbed by that same individual's personal history, conditioning him in what's to come. The system consists of a defense mechanism towards the threat of anguish, characterized by an "unfulfillment of the present" and by an escape to a world closed to communication, in which the patient remains condemned to a harsh necessity that no contingency can perceive as its shadow ${ }^{17}$.

\footnotetext{
${ }^{16}$ FOUCAULT, Michel: La recherché scientifique et la psychologie, in FOUCAULT, Michel: Dits et écrits I, 1965-1975, vol. 1, Gallimard, Paris, 2001. Pags. 137-158.

${ }^{17}$ FOUCAULT, Michel: Doença mental e psicologia, Edições Texto \& Grafia Lda, Lisboa, 2008. Pag. 69. See also BINSWANGER, Ludwig: Introduction à l'analyse existentielle, Editions de Minuit, Paris, 1971. Pag. 131.
} 
Mental illness is therefore the result of an unsolved intra-psychic conflict, to which contradictory solutions were adopted, whose outcome is an aggravation of that same conflict. Wrong solutions for ambivalence are responsible for new anguish crisis. That which distinguishes the psychic morbid universe from what can be considered healthy mental activity and behaviour is merely the response of the individual to his experience of ambivalence. Analysis tries to release the patient from this vicious circle. Ambivalence holds as an indelible feature of the entire psychological frame.

With L. Binswanger, more importance was given to the anthropological and existential dimension of the patient. The Dasein Analysis places in the centre of its approach the significance that the patient gives his experience, his ethical way of being in the world which never entirely gives in to positivity, even when the individual refers to himself - he will always be another one talking about himself. The "hysterical" symptom, for example, is a way of expressing an experience, which no longer finds any chances of achievement in language or communication, thus imprisoning his meaning in body language at the level of the vital function. Returning the speech to an ill individual is, thus, the purpose of the Dasein Analysis. However, by doing so, it doesn't eliminate the inevitable contradictions of experience. Just the possibilities of searching beneficial meaning to experience are enlarged.

These examples allow an understanding of how the course of the individual's positive science met the aforementioned statement of $\mathrm{M}$. Foucault. Positivity never ceases to project its negative shadow. Psychology can't set the man free from the great tragic confrontation with madness. ${ }^{18}$

Psychology has, therefore, reached its limit. Not in the sense that there's nothing else to be added to our knowledge of the human individual, but in the sense that, from now on, we can only push that limit further without ever really breaking it. That's why it necessarily hushes when it comes to ethical-existential salvation: it can't lead to nay ultimate solution for the difficulties inherent in the process of individualization. As M. Foucault wrote:

${ }^{18}$ FOUCAULT, Michel: Doença mental e psicologia, Edições Texto \& Grafia Lda., Lisboa, 2008.Pag. 88. 
impelled into its roots, psychology of madness will not be the domination of mental illness, thus the possibility of its disappearance, but the destruction of psychology itself, and the restoration of the essential relation (...) between reason and unreason $^{19}$

Its usefulness is obviously not at stake. We only find its limit and define its working field on the inner side of that limit, being that with this observation a whole new discursive field is opened and responsible for the constant and ever endless task of articulating the breakthroughs of that side of the limit with the subsequent breakthroughs of the other. That's why Psychology is a starting point to Philosophical Counseling and this cannot move forward without it.

This must be taken under account to understand why, after the empowerment of Psychology as a positive science, the question of Philosophy's role regarding the treatment of uneasiness was posed again. It wasn't Psychology that, forgetting its philosophical origins, strayed away and set to regard uneasiness as an illness. As we saw, it evolved to incorporate ethical and existential questions in its study and application field. What actually happened is that its development made contemporary Philosophy renew itself and question its responsibilities towards the comprehension and relief of uneasiness, which science itself recognizes as something constitutive of human experience.

Uneasiness takes on, yet again, a philosophical dimension that leads us to consider it from the ethical and existential point of view and to ask to which extent it can be handled as a problem related to the "personal philosophy of life". Only at that moment can a philosophical aiding practice appear, acquire a reason for being and gain justification. Once the constitutive fracture of the human individual is recognized - or of the perception that he necessarily has of himself, the hypothesis of Philosophical Counseling can be placed, although as problem of knowing to which extent the clarifications provided by science can contribute to the formation of a wisdom one can access through a philosophical practice capable of appeasing uneasiness.

${ }^{19}$ FOUCAULT, Michel: Doença mental e psicologia, Edições Texto \& Grafia Lda, Lisboa, 2008. Pag. 88. 


\section{Nostalgia towards the "golden age" of Ancient Philosophy}

When crossing the criticism of "academic Philosophy" with the feeling that Psychology hushes before the fundamental, we find in the literature about Philosophical Counseling, a certain nostalgia regarding ancient Philosophy.

One elevate an irreducible attitude towards contemplation and the dispute of speculative points of view. This attitude resists the separation between the theoretical demand for knowledge and the personal and collective desire for a good life; an attitude to which there is no distance between truth and living well, nor isolation of the mind towards the world, in which, through their actions, individuals take on an ethical position regarding the community and most of all, themselves.

This attitude, as M. Foucault wrote, is embedded in the frame of "the Culture of the Self", which has reached the dimension of a cultural phenomenon. A thorough study on the evolution of the theme "Care of the Self" from the $5^{\text {th }}$ Century BC to the $5^{\text {th }}$ Century AD, was carried out by. M. Foucault, at Collège de France, from 1981 to $1984^{20}$.

In that study the author showed how the principle of epimeleia heauton (Care for Yourself), carved on the Delphic commandments, was a widespread feature in Greek culture. One of the ancient testimonies of this principle is proffered by Plutarch following the Spartan Alexandridis's statement where, as means of justifying the aristocracy's laziness, he says that superior men delegate productive tasks to inferior men so that they can care for themselves ${ }^{21}$. Meanwhile its significance changed, especially after the Socratic-Platonic recommendations to give up the wealth and privileges of the social status, the criticism to bad habits acquired through social mingling and the interests of less honest men, that characterize the relationship between the masters and the young disciples. The first step towards the Care for the Self compels us to focus on ourselves in order to find out how ignorant and how ignorant of our

\footnotetext{
${ }^{20}$ FOUCAULT, Michel: L'Herméneutique du sujet. Cours au Collège de France, Seuil/Gallimard, Paris, 2001. See also FOUCAULT, Michel: L'Herméneutique du sujet. Cours au Collège de France, 1981-1982, Seuil/Gallimard, Paris, 2001.

${ }^{21}$ FOUCAULT, Michel: L'Herméneutique du sujet. Cours au Collège de France, Seuil/Gallimard, Paris, 2001. Pag. 33.
} 
ignorance we are. The Delphic commandment gnôthi seauton (Know Yourself) then becomes of great importance in philosophical activity, however, as M. Foucault shows, knowledge was not an end in itself, nor was the access to truth something that could be done without a transformation of the subject's being. As opposed to what eventually happened in modernity, knowledge was not granted by the subject's cognitive structures or by the methodical use of the thought. An entire work of the subject towards himself was necessary for him to be able to know himself. A double movement was assumed, through which, by transforming himself, the subject would reach the truth and truth would fall on him completing his transformation and allowing him to wisely lead his life. The commandment that prescribes that the individual knows himself was subordinated to the commandment that exhorted the Care of the Self and it was nothing but one of its expressions and one of its moments.

Throughout a thousand years, the matter of the Care of the Self blossomed and gave rise to a multiplicity of versions. In the first three centuries of our era, it was asserted as the main task of a Philosophy fulfilled as true practice of itself. It was not merely about looking at the world an oneself, but about a more general attitude which included a set of exercises and techniques, such as memorization, endurance, concentration exercises, examination of conscience and meditation, among other "technologies of the self".

This work of the subject towards himself started off, as philosophical theme, with Plato, as a moment of preparation for public jobs or for the wellbeing of the community. The governor or the clerk should know themselves and care for the perfection of their souls so that they can take on the job of caring for the other. The dialogue between Socrates and Alcibiades illustrates this ambition of philosophically driven governance. However, these ambitions will eventually give rise to a thematization in which the subject himself is the ultimate goal of the care for himself. The subject exercises to reach the truth but what is at stake now is not just the preparation for a civic and political life. Philosophical practice has become an applicable commandment to all individuals, regardless of their status or age. It is of everybody's interest and responsibility to fulfill life in the possible way. 
On the other hand, what is being attempted to achieve cannot be mistaken for science's modern objectivity. It is in fact about making truth more subjective and interior shaped by practical principles of conduct, available in the subject himself to guide him under any circumstance. It's not really about knowing the truth but about acting well based on it.

Knowledge is, therefore, a necessary moment in the formation of practical wisdom. To become enlightened means to be able to live righteously and authentically.

An authentic life is the one in which the subject is engaged in internalizing true principles of conduct, a life in which he is willing to apply techniques that will allow his transformation, and that is considers "care for oneself" in the sense that, what is at stake is a preparation for a victorious confrontation with uneasiness. By means of that care, what is intended is freedom from passion related dependencies, which imprison the subjects to the whims of the body, desires and material goods. M. Foucault shows that it is not about a negation of the self, as it would happen later on with the Christian thematization of the "care of the self" and its figures of confession and penitence, but about fulfilling himself completely, regardless of the possibilities available in the world. It is about a release reached by means of interiorization that the only reasons for concern are the ones that entirely depend on the subject's capacity and that everything that is not dependant of his will, can't actually be missed. Death itself ceases to be feared. It is an indispensable moment of life against which it doesn't make sense to fight. The Care for the Self is ultimately a preparation for a full freedom towards life itself and for an unbreakable easiness of the soul. To live authentically is to live well and to be ready to face evil. There was a path between enlightenment and appeasement in this culture.

That is the path Philosophical Counseling attempts to restore nowadays, returning Philosophy to daily life and giving back the individual the chance to ethically mind with his uneasiness. Under the influence of a somewhat nostalgic look, the ancient "art of existing" acquires and almost relieving coloration and we attempt to rescue it in its value of care for human misery. Academic Philosophy is then released from universities and placed in daily life. One dreams of an aiding service 
in which the philosopher regains his role of counselor and conscience guide.

Some coherence seems to lack, though, regarding the perception that which difficulties which nowadays may lead one to search Philosophical Counseling are due to the complexity of the society we live in.

The evolution of a philosophical practice as "art of existing" is now connected to the evolution of society itself and, as M. Foucault shows, that was in ancient times one of the ways found to provide an answer to the problems aroused by the environment ${ }^{22}$. Throughout this process, there have been changes in the centers of political power, military relationships and the schemes of economic and family dependencies. Caring philosophically of the self constituted a semantic arrangement and a possible practical guidance to face the challenges of society at the time.

The internal structure of society, however, has deeply changed, as well as its relations with the psycho-physical environment. We no longer live in a strictly stratified society, politically centered, in which the rigid distribution of access to communication would allow the individual to find the essential of his identity in his belonging group, in the status or tasks assigned to him in the hierarchy. His form no longer provides the basis for the representation of a unit of a cosmos in which all entities are organized according to their specific nature, task or degree of ontological perfection in the whole. The world can no longer be conceived as independent of all observation, in which, previously, all beings settle themselves in their own places. Knowledge is no longer perceived as gradual movement of liberation from ignorance, but as ignorance in motion. It is no longer thinkable as a product of a wise mind, but as specific communicative activity that will never reach full truth or a unitarian meaning of the world. As E. Balsemão Pires mentioned in his reflection about the tasks of Philosophy after the Theory of Social Systems, the shape of society no longer fits a metaphysics of

\footnotetext{
${ }^{22}$ FOUCAULT, Michel: Histoire de la sexualité - III. Le souci de soi, Gallimard, Paris, 1984. Pags. 55-94.
} 
topographically located things, it does however fit a semantics of "selfgenerated uncertainty" ${ }^{23}$.

This evolution has not eliminated the individual needs of existential meaning and practical guidance, but placed them facing new challenges. As we have seen, the scientific expertise of the communicative function of knowledge has increased our explanatory capabilities and our power of transformation technique, but it is no longer able to represent the unit of meaning of the individual, the society and the world. There is a reason why, in the post-scientific society in which we live, think, act and communicate, we feel the difficulty to convert knowledge into practical wisdom. Despite the extension of our perceptive possibilities and the extraordinary advances of techno-science, the undeniable progress in health care, nutrition and comfort, we recognize our society as inhospitable, in which it is difficult to know who we are and which conducts allow us to feel accomplished; an environment in which we are hardly able to determine an ultimate purpose for our lives in which we must concretely deal with a whole list of miseries, an expression of which is the appalling current suicide rate. As noted by M. Foucault, knowledge can no longer save the subject. ${ }^{24}$

The challenge is to develop ways of thinking these misplaced realities that science reveals, trying to provide them with meaning from its constitutive otherness, and not from the assumption that there is an ultimate, final and single meaning for all things and for the totality they form. All these metaphysical categories which served to support the old philosophical practice succumbed under the pressure of the evolution of society. Little longer do they serve us regarding the determination of our place in the world and the distinction of the real purpose of life and ethical means to achieve them.

\footnotetext{
${ }^{23}$ BALSEMÃO PIRES, Edmundo: Mundo e Individuação. A Teoria dos Sistemas e as Tarefas da Filosofia, in Centro de Filosofia da Universidade de Lisboa (org.), Razão e Liberdade. Homenagem a Manuel José do Carmo Ferreira, volume I, Lisboa, 2010. Pags. 571-605.

24 (...) C'est que l'accès à la vérité, qui n'a plus désormais pour condition que la connaissance, ne trouvera dans la connaissance, comme récompense et comme accomplissement, rien d'autre que le cheminement indéfini de la connaissance. Ce point de l'illumination, ce point d'accomplissement, ce moment de la transfiguration du sujet par "l'effet de retour" de la vérité qu'il connait sur lui-même, et qui transit, traverse, transfigure son être, tout ceci ne peut plus exister. (...) Telle qu'elle est désormais, la vérité n'est pas capable de sauver le sujet (FOUCAULT, Michel: L'Herméneutique du sujet. Cours au Collège de France, Seuil/Gallimard, Paris, 2001. Pag. 20).
} 
We understand the nostalgia for the philosophical practice developed within the frame of the ancient "culture of the self". It is one of those times of wistful reading because back then you could think of a coincidence between the authenticity of life and its full and quiet fulfillment, times in which reason was the instrument of enlightenment and clarification was a way of appeasement.

But that time has gone, that society no longer exists. Like all the "golden ages", this is a lost era to which it is impossible to return. With the emergence of Philosophical Counseling, is the theme of epimeleia heauton that is updated. But there is no full coincidence between our problems and those of our ancient Greeks and Romans. Their solutions cannot be directly imported into a time when relations between truth and subjectivity have profoundly changed and when the relations system environment are characterized by a high degree of complexity and contingency. The nostalgia for the "golden age" of the ancient philosophical practice can no longer make us fall in love to the point of forgetting that what really stimulates Philosophical Counseling is a set of very current problems that require modern solutions with all the difficulties that come with it.

$*$

The idea that the problems which lead to Psychological Counseling are the outcome of environmental complexity has lead us to question the presupposition of a direct relationship between enlightenment and appeasement. The discussion around "academic Philosophy" has shown us that the modern crossing between structure and semantics makes the "world" disappear in the unit of its thinkable and communicating meaning. The analysis of the limits of Psychology has shown us that the scientific knowledge of the individual is a system of irreducible differences, in permanent confrontation with its own denial and with the threat of anguish. Nostalgia towards the past of Philosophy has indicated that the current communicative conditions impose new problems to which it is necessary to find a practical rationality, which doesn't allow modernity to be a blank slate.

These four feelings show us the main problem to which Philosophical Counseling should find an answer to. The contemporary appearance of 
this specifically philosophical aiding practice is due to the perception of what is problematic in the relationships between enlightenment and appeasement. Where the eldest ancient used to find an intelligent and intelligible cosmos, structured according to natural hierarchy replicated at a smaller scale by the stratified society and carrier of an indisputable truth which solely awaits to be known, we find an irreducible "multiverse" in a unique structure, refractory to univocal knowledge, divisible and multipliable in indefinite and peculiar layers of organization, always haunted by its own shadow and whose forms are no longer apprehensible in terms of an ontological fixation, but merely as operations of codifferentiations through which, at different times, one can reach an always precarious landmark to describe a world understandable as ephemeral update of endless possibilities. Our perception is that we are located under the gap of two abysses. That is where Philosophical Counseling becomes a decision. To distinguish the opportunities, the limits and the means by which the search for enlightenment may be articulated with the search for ethical-existential appeasement is the task that the self-reflexive exercise imposes to the reflection of this new field.

\section{References}

BALSEMÃO PIRES, Edmundo: A Sociedade sem Centro Diferenciação funcional e unidade política da sociedade. A partir da obra N. Luhmann, Autonomia 27, Azeitão, 2004.

BALSEMÃO PIRES, Edmundo: O pensamento de Niklas Luhmann como teoria crítica da moral, in SANTOS, José Manuel: $O$ pensamento de Niklas Luhmann, Lusosofia press, Covilhã, 2005. Pags. 253-280.

BALSEMÃO PIRES, Edmundo: Mundo e Individuação. A Teoria dos Sistemas e as Tarefas da Filosofia, in Centro de Filosofia da Universidade de Lisboa (org.), Razão e Liberdade. Homenagem a Manuel José do Carmo Ferreira, volume I, Lisboa, 2010. Pags. 571-605. FERRAZ, Lara Sayão: A necessidade de Exercer o que é Próprio do Homem, in Dias, Jorge: Encontros Portugueses de Filosofia Aplicada, APAEF, 2008. Pags. 17-27. 
BINSWANGER, Ludwig: Introduction à l'analyse existentielle, Editions de Minuit, Paris, 1971.

FOUCAULT, Michel: Histoire de la sexualité - III. Le souci de soi, Gallimard, Paris, 1984. Pags. 55-94.

FOUCAULT, Michel: La psychologie de 1850 à 1950 (1957); La recherche scientifique et la psychologie (1957), in FOUCAULT, Michel: Dits et écrits I, 1965-1975, vol. 1, Gallimard, Paris, 2001. Pags. 120-167. FOUCAULT, Michel: L'Herméneutique du sujet. Cours au Collège de France, 1981-1982, Seuil/Gallimard, Paris, 2001.

FOUCAULT, Michel: Doença mental e psicologia, Edições Texto \& Grafia Lda., Lisboa, 2008.

FOUCAULT, Michel: Le Gouvernement de soi et de les Autres. Cours au Collège de France, 1982-1983, Seuil/Gallimard, Paris, 2008.

LUHMANN, Niklas: A improbabilidade da comunicação, Vega, Lisboa, 2006.

LUHMANN, Niklas: Comunicación y sociedad; Diferenciación social y sociedad moderna, in LUHMANN, Niklas: Complejidad y modernidad: de la unidad a la diferencia, Editorial Trotta, Madrid, 1998. Pags 25-67; 71-212.

LUHMANN, Niklas: La Ciência de la Sociedad, Universidad Iberoamericana, A.C., Lomas de Santa Fé (México), 1996. Pags. 13-91. MARINOFF, Lou: Mais Platão, Menos Prozac, Editorial Presença, Lisboa, 2001.

MARINOFF, Lou: As Grandes Questões da Vida, Editorial Presença, Lisboa, 2005.

MENEZES, Filipe M.: A ideia geral do "Aconselhamento Filosófico". Uma introdução ao tema, in Revista Filosófica de Coimbra, n. ${ }^{\circ} 39$, vol. 20, Universidade de Coimbra, 2011; Pags. 101-140.

RAABE, Peter: Introducción: Mentes, Cerebros y Filosofía Aplicada, in: DIAS, Jorge e RASTROJO, José Barrientos: Felicidad o Conocimiento?, Doss Ediciones, Sevilha, 2009. 


\section{COMENTARIOS E INFORMES/ COMMENTARIES AND REPORTS}


